La littérature est précisément abordée dans huit études, dont les thèmes sont les suivants : une source de Béroalde de Verville, Cristoforo Armeno (D. Mauri), l'Orient chez Montaigne (J.-C. Ternaux), le Liber Proverbiorum de Lorenzo Lippi (P. Rondinelli), le Morgante de Pulci (M. Ballarini), les Octavas de Francisco de Aldana (V. Nardoni), Fernando de Herrera (G. Chiappini), la lyrique amoureuse de la fin du XVI ${ }^{e}$-début du XVII ${ }^{e}$ siècle (A. Colombo), ainsi que la perception de l'Orient dans la littérature hongroise (A. Di Francesco).

Enfin, l'art n'est pas oublié puisque sont examinés Piero della Francesca (A. Ceccarelli Pellegrino), l'impact des arts de l'Islam sur l'Europe (A. M. Martelli puis F. F. d'Arcais), l'architecture (L. Patetta puis M. Cerasi), et les rapports entre l'architecture et l'art pour la représentation de la cité orientale à la Scuola Grande di San Marco (T. Patetta).

On trouvera donc dans ce volume des études très précises et très fouillées (les notes abondantes sont une véritable mine d'informations), dont la diversité n'est pas un obstacle à la lecture, bien au contraire. Elle oblige le lecteur moderne à sortir de sa spécialité, à accéder à un univers culturel complexe dont il a bien souvent perdu non seulement les clefs mais même les éléments principaux.

François roudaut, Université Paul Valéry III, Montpellier

\title{
Terjanian, Pierre.
}

Princely Armor in the Age of Dürer: A Renaissance Masterpiece in the Philadelphia Museum of Art.

New Haven: Philadelphia Museum of Art in Association with Yale University Press, 2011. Pp. 54. ISBN 978-0-300-17631-5 (paperback) \$18.

In 2009 the Philadelphia Museum of Art acquired an exquisite horse armour originally commissioned in 1507 by the flamboyant German prince, Duke Ulrich of Württemberg. The decorative plate armour - a stunning product of the age of Dürer - was the work of the highly respected Nuremberg armourer Wilhelm Von Worms the Elder and is considered "to be among the finest examples of European armor anywhere" (5). Pierre Terjanian, the museum's associate curator of Arms and Armour, has produced a beautifully illustrated catalogue to mark the acquisition and public unveiling of the horse armour and 
accompanying armour for a man, the work of Matthes Deutsch of Landshut, who was a contemporary of von Worms. The horse armour, or bard, is unique in many respects; not only is it a fine representation of the new Renaissance style of the early sixteenth century, but it is one of the few complete horse armours from the period. Terjanian also has been able to accurately date the armour as well as uncover much about the process that went into its creation and the close business relationship between patron and artist.

Terjanian's 54-page catalogue is more than just a description of armour for horse and man; it is also a case study of collaborative art in Germany in the late fifteenth and early sixteenth centuries. Readers are first introduced to the flamboyant young Duke Ulrich, who commissioned the bard from von Worms on the eve of accompanying the new Holy Roman Emperor Maximilian I to his coronation in Rome. To impress the emperor, the other German princes in attendance, and the Roman audience, Ulrich called on von Worms to create a masterpiece that would reflect his wealth, status, and princely ambitions (and also put the other princes to shame). Bards, notes Terjanian, were "coveted objects with potent symbolic association" (15) and their exorbitant cost - Ulrich paid 600 florins for his - meant they were only available to the wealthiest knights. Ulrich sought out the services of von Worms because of his reputation as the armourer to the nobility, and the relationship proved to be a long and happy one, with the duke still ordering armour from von Worms in the late 1530s. Where the 1507 bard was concerned, the duke was not content to commission the armour and wait patiently for its arrival. Terjanian uncovered documentary evidence revealing that Ulrich corresponded with the armourer and with municipal officials in Nuremberg to assure that the work was completed on time and to his specifications. So pressing was Ulrich's project that it required the hiring of additional journeymen to finish it on time.

Terjanian describes von Worms as the "consummate metalworker" (17), as much an artist as an armourer, producing tournament armour of the finest quality. His metallurgical skills were ably supported by a number of painters, goldsmiths, and engravers who were responsible for drawing and etching the designs of dragons, maidens, and hunting scenes onto the horse armour. The ornamentation these artists produced, using the technique of Goldschmelz etching, were luxurious and delicate works of art, most impressively represented by the dragon that festoons the shaffron or headpiece of the Philadelphia Museum's bard. 
While much of Terjanian's study is dedicated to the horse armour, Deutsch's armour for a man, which serves as the mounted rider in the museum's display of these pieces, is almost equally impressive in its design and decoration. Matthes Deutsch incorporated Goldschmelz ornamentation in the breastplate though polishing and age have worn away much of the gold decoration. Like the horse armour, Deutsch's armour is also unique, being one of the few complete field armours in the Renaissance style from German armourers. While the market for armour from Landshut was more localized than that of Nuremberg or Augsburg, Deutsch's ability to produce beautiful tournament armour meant his wares were sought after by Saxon and Bavarian princes. The style and decoration on Deutsch's armour were meant to imitate male dress of the period, another important aspect of the shift from Gothic to the Renaissance style. Unfortunately, the armour of the man receives less attention in the study, due in part to the author's admission that Deutsch's career is simply not as well documented as that of von Worms.

Pierre Terjanian should be commended for this well-researched study that breathes life into these two armours. Their journey from the forge to the Philadelphia Museum of Art's Kretzschmar von Kienbusch Galleries may have been long and arduous, but Terjanian's telling of the tale is anything but. Art historians, historians of arms and armour and masculinity will undoubtedly find this case study a very important addition to our understanding of the emergence of the Renaissance style as a "pivotal moment in the history of armor" (34). At the same time, his emphasis on the collaborative nature of the armourer's work in towns like Nuremberg, Augsburg, and Landshut raises interesting questions about the intersections between military culture and the arts in Renaissance Europe. Finally, readers will find the catalogue's extensive notes and select bibliography a very useful starting point for further study of Renaissance style German armour.

David R. LaWrence, Glendon College, York University 